\title{
«КУЛЬТУРНАЯ ПАМЯТЬ СЛОВА» И ЕГО СВЯЗЬ С ТВОРЧЕСТВОМ БУНИНА ПЕРИОДА ЭМИГРАЦИИ
}

\section{"CULTURAL MEMORY OF THE WORD" AND ITS CONNECTION WITH THE WORK OF BUNIN DURING THE PERIOD OF EMIGRATION}

\section{O. Petrenko}

Summary: In the article some linguistics points about problems of determination of the cultural memory of words are considered. The article proposes an approach to the elucidation of cultural memory of Russian words through the comparison the meaning of Russian words with the meaning of their translated equivalents in some cognate and not cognate languages with the support on their Etymology, different classes of the cultural memory of words as universal, Indo-European and specific, original characters, which reflect the history of development the people, are elucidated.

Keywords: cultural memory of words, comparison, translated equivalents, etymology.

\author{
Петренко Олеся Александровна \\ к.фрилол.н., дочент, ФГБОУ ВО «Брянский ГАУ» \\ brodyga_2008@mail.ru
}

Аннотация: В статье рассматриваются существующие в лингвистике точки зрения на проблемы установления культурной памяти слов. В ней предлагается подход к выяснению культурной памяти русских слов посредством сопоставления семантики русских слов с семантикой их переводных эквивалентов в ряде родственных и неродственных языков с опорой на их этимологию, выясняются разные виды культурной памяти слов универсального, индоевропейского и специфичного, самобытного планов, отражающих историю развития народа.

Ключевые слова: культурная память слов, сопоставление, переводные эквиваленты, этимология.
«Культурная память» языковой единицы (слова, фразеологизма) всегда являлась предметом интереса лингвокультурологов. Это те представления, которые задаются языковой единицей и организуют ее современное значение. Ведь любое слово нашей речи, прежде чем получить современное значение, прошло сложную семантическую обработку, ведущую нас в конечном счете к начальным семантическим усилиям человека. И сама культура - это своего рода прошлое, просвечивающее в настоящем. Чем глубже это прошлое, тем выше культура.

Судьба русской усадьбы, будучи частью отечественной истории, является отражением и закономерным результатом социально-экономических и историко-культурных процессов в России.

Одновременно с другими яркими явлениями жизни начала прошлого века феномен дворянской усадьбы, играя особую роль в индивидуально-авторской картине мира И.А. Бунина, не мог не наполниться знаковыми элементами, не выполнить роль той части пространства, которая была запечатлена в культурной памяти и творческом контексте. Поэтому изучение концепта «Дворянская усадьба» открывает скрытые элементы связи бунинского пристального внимания к данному концепту с глубинными процессами его творчества. Стоит обратить внимание на следующую деталь: если каждый из больших писате- лей эмигрантов разрабатывал свой «пласт» воспоминаний о Родине, воссоздавая главное в ее образе, если, например, для И. Шмелева и Б. Зайцева главной является мысль о Руси Православной, если у А. Ремизова - Русь архаическая, мифологическая, то для И.А. Бунина Русь - это прежде всего Русь усадебная [Зайцева 1999: 67].

С точки зрения культурной памяти, усадьба - «текст», в котором в виде кода хранится информация о жизненном опыте целого класса. Многовековая история усадьбы имеет огромное значение для И.А. Бунина, а также ее «родословная», которая дает ощущение укорененности, ощущение огромной внутренней связи между поколениями, столь важное для самого писателя и для многих его героев.

Например, в 1917 году писатель делает такую характерную дневниковую запись: «Деревенскому дому, в котором я опять провожу лето, полтора века. И мне всегда приятно вспоминать и чувствовать его старину... я часто думаю о всех тех людях, что были здесь когда-то, - рождались, росли, любили, женились, старились и умирали... Они, - совсем неизвестные мне, - только смутные образы, только мое воображение, но всегда со мною, близки и дороги, всегда волнуют меня очарованием прошлого» [Дневники Бунина 1979: 113-121] .

Русская дворянская усадьба это несомненно величай- 
шее явление отечественной культуры. В чем же величие этого явления? Скорее всего, с уверенностью можно сказать, что усадьба одновременно была и благодатной почвой для развития материальной и духовной сфер жизни общества. «Усадьба представляет собой и факт реальной, материальной исторической культуры, и явление символическое, и даже мифологическое» [Соловьев 1998:14].

Необходимо четко различать следующие понятия. Реальная усадьба - это ее материальное воплощение (строения, интерьеры и т. п.). Усадебная мифология - некий семиотический срез (этический и эстетический), образа жизни, сформированного в произведениях художественной литературы, в музыке, живописи. Одна из центральных частей усадебного мифа - присущая дворянской усадьбе творческая атмосфера. Усадьба как идеал гармоничной жизни - особое представление об усадьбе, которое сложилось в определенном обществе и в конкретный период времени (оно включает в себя и фоновые знания по истории усадьбы, по истории ее культуры) [Трубина 1996: 6/19-25].

Усадьба обладала особой аурой, поэтому человека, родившегося в имении, но покинувшего его по той или иной причине, часто тянуло в него вернуться [Соловьев 1998]. Эти и многие другие черты усадебного быта не мог не осознать и не отразить в своем творчестве такой тонко чувствующий реальность художник, каким был И.А. Бунин, созданный им обобщенный образ логично включается именно в этот контекст русской литературной традиции.

Бунин интенсивно и плодотворно работал именно в самой усадьбе. Это подтверждала и его супруга В.Н. Муромцева-Бунина. Несмотря на огромное количество путешествий, и странствий он мысленно часто возвращался в родные места, в отчий дом, что нашло отражение в дневниках и художественных произведениях писателя [См. Муромцева-Бунина 1989].

Сравнение текстов различных периодов творчества писателя показывает не только устойчивость и важность в нем феномена концепта «Дворянская усадьба», но и то, что со временем содержание его меняется, приобретает особые специфические черты. Так, в творчестве Бунина в период эмиграции особый смысл приобретает мотив утраты родины. Он проскальзывал и ранее (рассказы «В поле», «Антоновские яблоки», стихотворения «Где ты, звезда моя заветная», «Старик сидел покорно и уныло» и др. произведения). В эмиграции же боль утраты приобретает особую остроту, потому что теперь он связан не только с утратой отчего крова (для Бунина это усадьба), но и с горечью утраты «большого дома» - России (невозвратимой утраты), и с утратой жизненной гармонии, воплощением которой был для И. Бунина мир русской дворянской усадьбы.
В эмиграции образ усадьбы приобретает ряд особенных черт, что связано, прежде всего, с отдельными моментами биографии писателя. Усадьба становится символом России. Ее образ теперь неразрывно связан с темой памяти. Поэтому гармонизация усадебного мира и даже некоторая его идеализация во многом обусловлены избирательностью памяти.

Воспоминания писателя, как справедливо отметила О.В. Сливицкая, «уже в глубинах сознания преобразованы и опоэтизированы, потому что существуют в эмоциональном поле тоски по навсегда ушедшему» [Сливицкая 1999: 97].

В произведениях этого периода Бунин художественно воссоздает мир русской дворянской усадьбы и его «исход» из жизни страны (как естественный, так и насильственный), который в творчестве писателя означает не окончательную смерть, а переход в другое состояние - воспоминание.

Необходимо отметить, что мир русской дворянской усадьбы является воплощением одной из важнейших основ человеческого бытия, утрата которой приводит к нарушению жизненной гармонии, эти нотки характерны для произведений Бунина периода эмиграции. Зная реальную судьбу усадьбы и внимательно наблюдая за событиями в России, в своих произведениях писатель «отпевает» Русь духовную, Русь «усадебную». Рассказ «Косцы» (1921 г., Париж) кончается так: «...хорошо знали и мы и они...что бесконечно счастливы были мы в те дни, теперь уже бесконечно далекие - и невозвратимые...и настал конец, предел божьему прощению» (5/72).

Если обобщить сведения, изложенные в данной статье, можно попытаться сформулировать, что является смысловым содержанием концепта «Дворянская усадьба», каким набором самых важных признаков обладает этот концепт как компонент русской концептосферы (и, следовательно, в русском языке) в целом и в представлении И.А. Бунина:

1. Имя данного концепта интересно отсутствием в его семантике семы, указывающей на происхождение собственности: «дворянская усадьба» - это лишь указание на наличие владения безотносительно к его происхождению (наследственное, награда за службу, покупка).

2. Классовая отнесенность (сема принадлежности определенному классу - русское дворянство).

3. Сопоставимость с характером изменений и развития русской деревни.

4. Сопоставимость характеристик усадьбы с характером владельцев и окружения.

5. Структурная сложность (наличие обязательных составляющих: господский дом, садово-парковый ансамбль, хозяйственные постройки). 
6. Наличие четырех направлений деятельности (социально-экономическое, духовно-эстетическое, воспитательно-коммуникативное, рекреационно-гостевое).

7. Противопоставленность городу.

8. Знаковость феномена (наполненность информацией об истории жизни и опыте отдельного класса в период18-начало 20 вв.).

Каждый из всех этих существующих признаков и средства его языкового выражения меняются в зависимости от того или иного периода в истории данного явления, в связи с изменением в характере и в связи со сменой культурной парадигмы (меняется удельный вес того или иного элемента; удельный вес определенной функции, роль религиозной составляющей, роль усадьбы как культурного и духовного центра на протяжении почти двух веков от зарождения, через рассвет и в период упадка).

Другую плоскость изменения структуры содержания концепта представляет взаимодействие компонен- тов, свойственных национальной картине мира, и индивидуально-авторских, выявленных и привнесенных И.А. Буниным в содержание концепта, например, различия в изображении им усадебной жизни в доэмигрантский и эмигрантский периоды, особое внимание к теме «вымороченности» [Мелехов 1997], к проблеме будущего русской деревни и роли в нем дворян.

Целью нашей статьи являлось выявление с опорой на перечисленные признаки набора языковых средств, участвующих в репрезентации концептуальной семантики, что позволит собрать структуру концепта «Дворянское гнездо», представляющую собой определенное поле, состоящее, в свою очередь, из нескольких микрополей [См. Попова, Стернин 2001].

Предложенный в статье подход установления культурной памяти слов путем сопоставления языков не является чем-то новым в языкознании, но он может расширить возможности проникновения в историю слов, которые выступают показателями культурной памяти языка.

\section{ЛИТЕРАТУРА}

1. Дневники Бунина / Публ., вступ. ст. и коммент. А. Бабореко // Подъем. 1979. №1. С. 113-121.

2. Зайцева Н.В. Концепция мелкопоместной усадьбы в творчестве И.А. Бунина 1890-х начала 1910-х годов: Автореф. дис. ... канд. филол. наук. - Елец, 1999. 19 c.

3. Муромцева-Бунина В.Н. Жизнь Бунина. Беседы с памятью. М.: Сов. писатель, 1989.512 с.

4. Осадчая 0.А. Лексика юго-западного пограничья в поле концепта «Дворянская усадьба» (на материале произведений И.А. Бунина) - Материалы 14 Международной научно-практической конференции «Традиционная культура на российско-белорусском пограничье: историко-этнографический и лингвокультурологический аспект». - Брянск, 2012.

5. Попова 3.Д. Очерки по когнитивной лингвистике / 3.Д. Попова, И.А. Стернин - Воронеж: Истоки, 2001. 189 с.

6. Попова 3.Д. Полевые структуры в системе языка. Воронеж: Воронежский государственный университет. 1989. С. - 196.

7. Сливицкая 0.В. О природе бунинской «внешней изобразительности» // Русская литература. 1994. - № 1. - С. 72 - 80.

8. Сливицкая О.В. Сюжетное и описательное в новеллистике И.А. Бунина // Русская литература. - 1999. № 1.-С. 97.

9. Соловьев К.А. «Во вкусе умной старины». Усадебный быт российского дворянства II половины XVIIII п половины XIX веков. По воспоминаниям, письмам и дневникам. Очерки. - СПб.: Нестор, 1998. 96 с.

10. Трубина Л.А. Тема памяти в литературе русского зарубежья. //Литература в школе. 1996. — № 6. - С. 19-25

( Петренко Олеся Александровна (brodyga_2008@mail.ru). 